\title{
An overview of the applicability of functional diversity in Biological Conservation
}

\author{
J. R. Freitas ${ }^{a *}$ and W. Mantovani ${ }^{a}$ \\ aPrograma de Pós-graduação em Ciência Ambiental - PROCAM, Instituto de Energia e Ambiente - IEE, Universidade de \\ São Paulo - USP, Avenida Luciano Gualberto, 1289, Cidade Universitária, CEP 05508-010, São Paulo, SP, Brazil \\ *e-mail: freitasjuliana.r@yahoo.com
}

Received: November 18, 2016 - Accepted: February 11, 2017 - Distributed: October 31, 2018

(With 2 figures)

\begin{abstract}
Functional diversity is increasingly pointed as a useful approach to reach Biological Conservation goals. Here, we provide an overview of the functional diversity approach status in the Biological Conservation field. We sought for peer-reviewed papers published over a period of twenty years (from 1994 to 2014). First we used the general topic "functional diversity" and then refined our search using the key-word "conservation". We have identified the conservation strategies addressed, the organism studied, and the continent of study site in each paper. Thirteen classes of conservation strategies were identified. Plants were the most commonly studied organism group and most study-sites were located in Europe. The functional diversity approach was introduced in the Biological Conservation field in the early 2000's and its inclusion in conservation strategies is broadly advised. However, the number of papers that operationalise such inclusion by developing models and systems is still low. Functional diversity responds differently and eventually better than other measures to changes in land use and management, which suggests that this approach can potentially better predict the impacts. More studies are needed to corroborate this hypothesis. We pointed out knowledge gaps regarding identification of the responses for functional diversity about urban impacts and in research on the level of management intensity of land needed to maintain functional diversity. We recommend the use of functional diversity measures to find ecological indicators. Future studies should focus on the development of functional diversity measures of other taxa beyond plants as well as test hypothesis in tropical ecosystems.
\end{abstract}

Keywords: biodiversity assessments, biodiversity measures, conservation strategies, ecosystem functioning, trait-based approach.

\section{Uma visão geral sobre a aplicabilidade da diversidade funcional na Conservação Biológica}

\begin{abstract}
Resumo
A diversidade funcional é crescentemente apontada como uma abordagem útil para alcançar os objetivos da Conservação Biológica. Neste artigo, nós mostramos uma visão geral do status desta abordagem no campo da Conservação Biológica. Nós buscamos por artigos revisados por pares publicados ao longo de vinte anos (desde 1994 até 2014) usando, primeiramente, o tópico geral "functional diversity" e em seguida, refinamos a pesquisa com a palavra-chave "conservation". Identificamos a estratégia de conservação abordada, o organismo estudado e o continente da área de estudo de cada artigo. Treze classes de estratégias de conservação foram identificadas. As plantas foram o grupo de organismos mais amplamente estudado e a maior parte das áreas de estudo estavam localizadas no continente europeu. A abordagem da diversidade funcional entrou no campo da Conservação Biológica no início dos anos 2000 e sua inclusão nas estratégias de conservação é amplamente recomendada. Entretanto, o número de artigos que operacionalizam tal inclusão ainda é pequeno. A diversidade funcional responde diferentemente e, eventualmente, melhor do que as outras medidas às mudanças no uso da terra e no manejo, sugerindo que essa abordagem pode potencialmente prever melhor os impactos. Mais estudos são necessários para corroborar esta hipótese. Destacamos lacunas de conhecimento sobre a identificação das respostas da diversidade funcional aos impactos urbanos e sobre a busca pelo nível de intensidade de manejo da terra necessária para manter a diversidade funcional. Recomendamos o uso de medidas de diversidade funcional para encontrar indicadores ecológicos. Estudos futuros devem focar no desenvolvimento de medidas de diversidade funcional de outros taxa, além das plantas bem como testar hipóteses em ecossistemas tropicais.
\end{abstract}

Palavras-chave: avaliações da biodiversidade, medidas de biodiversidade, estratégias de conservação, funcionamento dos ecossistemas, abordagem baseada em traços. 


\section{Introduction}

Biological Conservation aims to maintain ecosystem functioning and services (Meffe and Carroll, 1963). Ecosystem functioning is the set of matter and energy that flows through biotic and abiotic ecosystem components (Díaz and Cabido, 2001). As biological diversity is assumed to reflect ecosystem functioning reasonably, managers usually employ measures of species diversity in order to assess ecosystem functioning (Magurran, 2004; Ricklefs, 2003). Biodiversity indices most commonly used are those based on the number of species and their abundance, thus, they assume that each species contributes equally to ecosystem functioning (Magurran, 2004). However, ecosystem functioning is maintained by the interactions among species and with the environment such as photosynthesis, herbivory, pollination, seed dispersal, and nutrient cycling (Blüthgen, 2011; Hooper et al., 2005). As a consequence, the contribution of each species to the ecosystem functioning relies on its characteristics and interactions and not only on the species number (Tilman et al., 1997).

Functional diversity is a component of biodiversity that encompass species features and, as a consequence, may predict ecosystem functioning more precisely (Díaz and Cabido, 2001; Cianciaruso et al., 2009). Measures of functional diversity are based on functional traits, i.e. characteristics of species that can be measured at individual level and are related to species growth, reproduction and survival (Pérez-Harguindeguy et al., 2013; Cornelissen et al., 2003). The trait-based approach is closely related to the niche models: different species complement each other by raising efficiency of processes, while similar species substitute each other by raising ecosystem resilience (MacArthur, 1972; Blüthgen, 2011). Indices of functional diversity measure how species are distributed in the multidimensional niche space (Petchey and Gaston, 2002, 2006 ; Villéger et al., 2008; Mouchet et al., 2010).

The concept of functional diversity and the trait-based approach are not new (Grime, 1998; Gitay and Noble, 1997). Until the 1990s ecologists were mainly interested in creating classification systems focused on the role of species in ecosystems by explaining how traits were influenced by biotic and abiotic factors, and finding distribution patterns for these groups (Laureto et al., 2015). The growing concern regarding global environmental changes during the 1970s and 1980 s, the consolidation of Biological Conservation as an interdisciplinary science field during the 1980's (Franco, 2013; Meine, 2010), and the United Nations' Conference on Environment and Development in 1992 (so-called Rio-92) raised the necessity of understanding the impacts of human activities on the biological diversity. Hence, during the 1990s, scientists gradually changed the focus of functional diversity questions towards the relationships between species traits and ecosystem functioning and services (Hooper et al., 2005; Srivastava et al., 2009; Díaz et al., 2007; Díaz and Cabido, 1997).

An increasing number of authors has pointed out functional diversity approach as useful to reaching biological conservation goals (Cadotte et al., 2011; Cadotte, 2011; Gillison et al., 2013; Isbell et al., 2011; Schwartz et al., 2000; Trindade-Filho and Loyola, 2011, 2010; Trindade-Filho et al., 2012; Trivellone et al., 2014). Assessments on the status of functional diversity approach in Biological Conservation issues elucidates knowledge gaps that may be useful to both functional diversity and conservation fields by improving the connection between them.

Here, we review the literature on functional diversity and biological conservation, evaluate trends, and identify knowledge gaps. Our review was guided by following five questions: 1) How many papers regarding functional diversity have been published over time? 2) Among them, how many are related to biological conservation? 3) On which conservation strategy are they focused? 4) How are these studies distributed among different organisms? 5) How are the study-sites' locations distributed around the world?

\section{Methods}

We considered peer-reviewed papers published over a period of twenty years (from 1994 until 2014) in journals concerning Agricultural, Biological, and Environmental Sciences using the Elsevier's leading platform of peer-reviewed scholarly literature (Elsevier, 2015). We began with the general topic "functional diversity" and then we refined the search with the key-word "conservation". After reading the abstract, we excluded papers that did not concern ecology (for instance, conservation of functional diversity of enzymes and proteins' structures). We also excluded papers out of this revision scope - where authors measured functional diversity using taxonomic indices and/or defined 'functional diversity' unclearly, as well as papers in which the relationship of the findings and biological conservation were not clear. After exclusions, we identified the conservation strategies addressed in each paper. Finally, we classified them according to the organism studied and the continent of site study.

\section{Results}

In total, we compiled 621 documents regarding functional diversity and, from those, 60 papers regarding functional diversity and biological conservation (see Figure 1). Nine papers were placed out of the scope, so we considered 51 in this revision. The number of papers regarding functional diversity and conservation represented approximately $8.2 \%$ of published papers on functional diversity overall. We identify the presence of functional diversity in academic papers since the beginning of the studied period (i.e. 1994) and the number of published papers is increasing (see Figure 1). Regarding conservation issues, functional diversity appeared for the first time in 1998. It appeared once again in 2001, remaining absent until 2005 and scarce until 2012, when it starts to increase significantly.

We identified thirteen classes of conservation strategies: biodiversity assessment (16 papers), impacts 
of land use (11), management (8), spatial conservation planning (8), indicator (7), ecosystem services (6), habitat loss (3), restoration (3), monitoring (2), priority areas (2), biological control (1), economic valuation of biodiversity
(1), and resilience (1). The sum of papers classified here (68) is higher than the total number of papers considered in this revision (51) because some papers were placed in more than one strategy (see Figure 2A). We found nine classes of

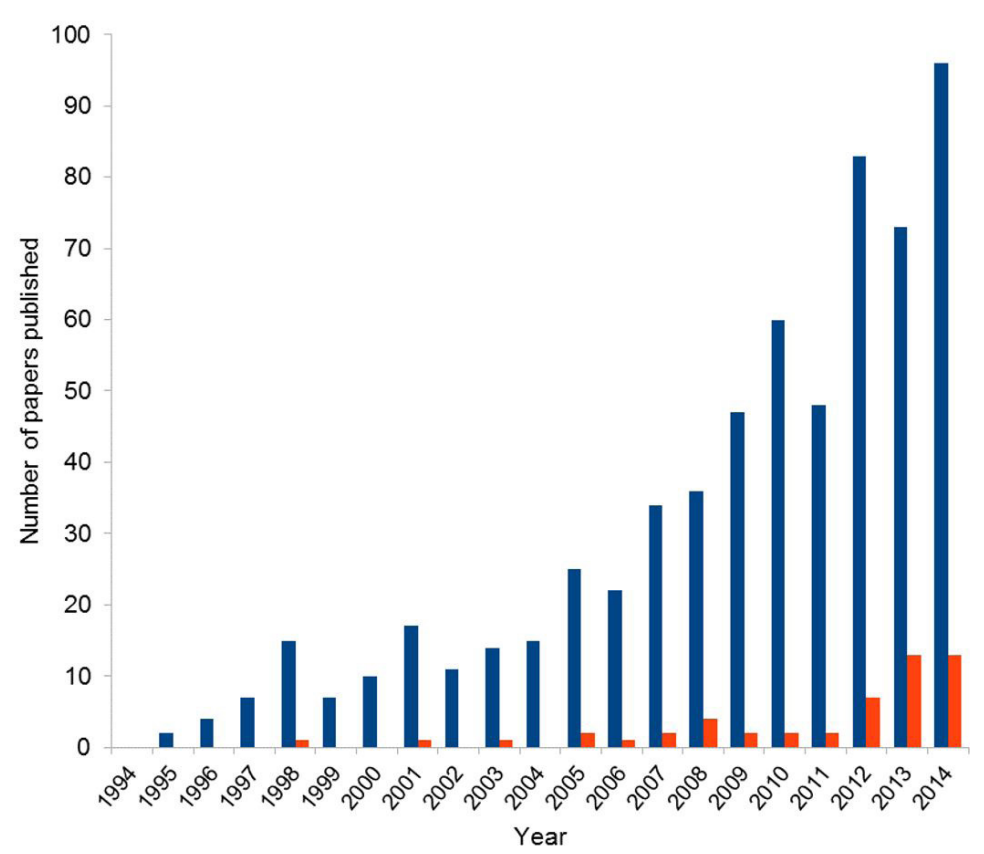

Figure 1. Number of papers published per year between 1994 and 2014 regards functional diversity (blue) and functional diversity and conservation (orange).

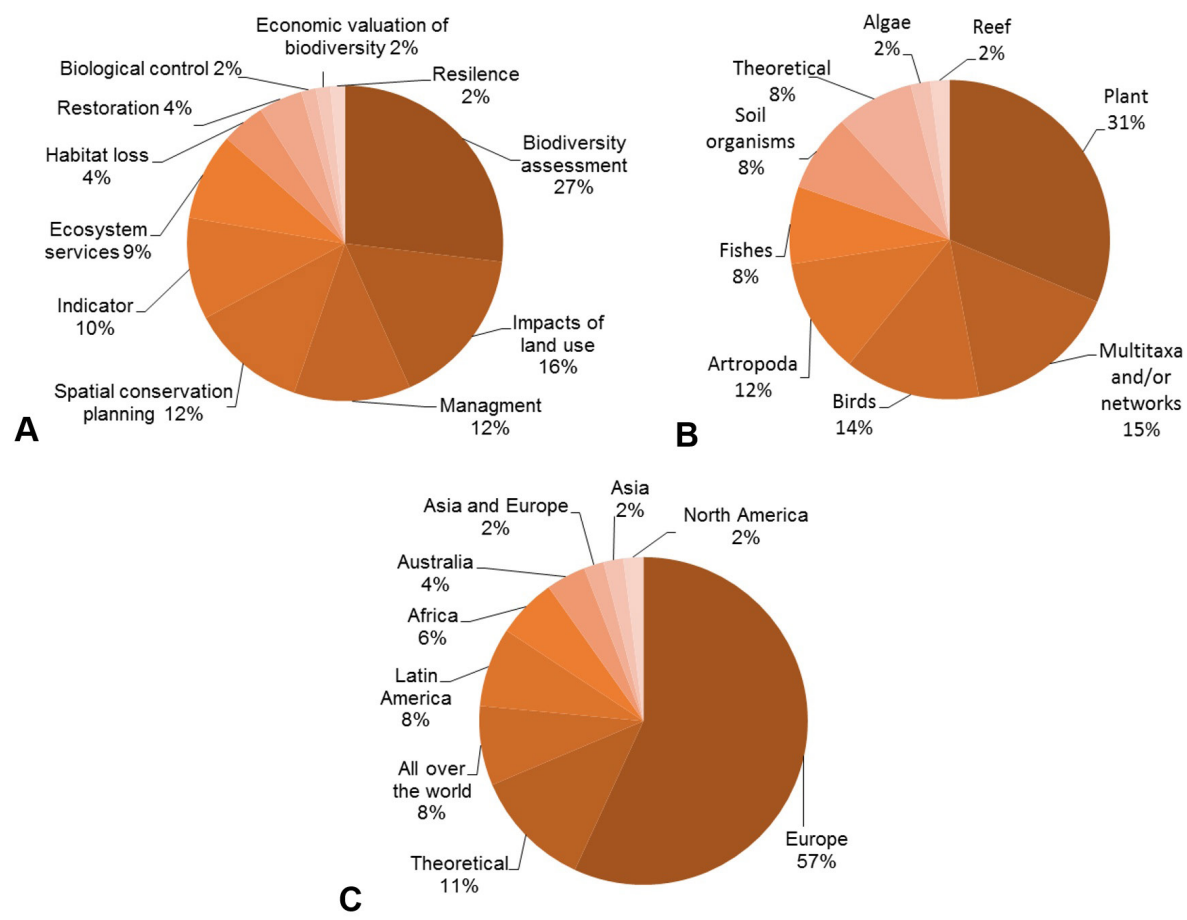

Figure 2. Distribution of papers focused on functional diversity and conservation published between 1994 and 2014 according to (A) conservation strategies, (B) organism studies, (C) continent of the study site. 
organisms: plant (16), multitaxa and/or networks (8), birds (7), Arthropoda (6), fish (4), soil organisms (4), theoretical (4), algae (1), and reef (1). Soil organism class included all organisms that live in the soil, excluding Arthropoda - for instance, earthworms, bacteria, fungi, lubricious, nematodes, and saprophytic organisms. Theoretical was the group that encompassed papers related to theoretical issues and discussions without focusing on a particular organism or group. Networks and/or Multitaxa encompassed papers that studied more than one organism, considering interactions between them or not (see Figure 2B). We found nine study site categories: Europe (25), theoretical (6), Latin America (4), all over the world (4), Australia (2), Africa (1), Asia and Europe (1), Asia (1), and North America (1). Similarly to organism classification, theoretical was the group that encompassed papers concerning theoretical issues and discussion without focusing on a particular study site. The class "all over the world" encompassed papers that used metadata or data on more than three continents and focused the discussion at a global level (see Figure 2C).

\section{Discussion}

Publications about functional diversity have increased over time. Pioneer research groups published the first papers which were read by other groups. Once they incorporated the knowledge, began to publish which increased the number of papers published in that field. Until the early 2000's the functional diversity concept had been developed only in a disciplinary approach, restricted to the academic community (see Figure 1). Once has entered the Biological Conservation field, which is interdisciplinary, the paradigm is expected to change: an extended peer community may contribute to develop, apply, and improve the knowledge, including academic, from other fields, governmental agencies and non-governmental organisations (Francis and Goodman, 2009; Funtowicz and Ravetz, 1993; Turnhout et al., 2007).

In the first paper about functional diversity and conservation, published in 1998, authors compared functional patterns with plant composition and concluded that functional diversity does not necessarily follow the same patterns as the species diversity (see Figure 1). Thus, they recommended the inclusion of functional trait-based approach in conservation strategies (Médail et al., 1998). This recommendation was enhanced in 2001 in a review showing links between plant functional diversity and ecosystem functioning (Díaz and Cabido, 2001). It became a key-paper uniting conservation and functional diversity.

Biodiversity assessments were the most common issue found in the analysed papers (see Figure 2A). Most of them focused on the responses of different metrics of biological diversity to environmental and spatial variation, including functional diversity and also phylogenetic diversity, relative rarity, ecological specialisation, and acoustic diversity (Schirmel et al., 2012; Schuldt et al., 2013; Winter et al., 2013; Gasc et al., 2013; Leroy et al., 2014; Granger et al., 2015; Bennett et al., 2014; Dengler et al., 2014; Callisto et al., 2001). Overall, authors recommend the inclusion of other facets of biodiversity beyond traditional indices on conservation strategies, with emphasis on functional diversity. However, the number of papers that operationalise such inclusion by developing models and systems that encompass functional diversity is still low (Robinson et al., 2014; Perry, 2010; Mouillot et al., 2008; Kadoya et al., 2011; Maire et al., 2013).

Papers classified as impacts of land use, management, and spatial conservation planning were the second, third and fourth classes of conservation strategies, respectively (see Figure 2A). Functional diversity responds differently to changes in land use and management than other measures, particularly the traditional ones showing that conserving other diversity components (such as species number or abundance) will not necessarily conserve functional diversity (Bennett et al., 2014; Katovai et al., 2012; Van Capelle et al., 2012). In some cases measures of functional diversity or trait-based approach responded more precisely than other measures (Dengler et al., 2014; Pelosi et al., 2014), suggesting that this approach can potentially better predict the impacts, although other corroborative studies are needed.

Among the papers regarding impacts of land use, only one was addressed to the impacts of urbanisation (Filippi-Codaccioni et al., 2009). They observed that extreme ages of urbanisation (young and old) cause higher niche differentiation concerning specialisation of birds, leading to a more vulnerable state for the ecosystem. Because farming is highly damaging to wild Nature, the high number of papers concerning agricultural land use is justifiable (Balmford et al., 2012; Swinton et al., 2007). Still, more studies about the responses of functional diversity to urban impacts are wanted.

Overall, land use intensification such as tillage, mowing, use of tracked mowers and increased nitrogen deposition had negative impact on functional diversity of different organisms (Pelosi et al., 2014; Lilleskov et al., 2011; Krause and Culmsee, 2013). While there is a relative consensus that reducing the land use intensification may contribute to maintain functional diversity, land abandonment also seems to have negative impacts (Fontana et al., 2014). Thus, the challenge thereafter is to find the optimum intensity management of land in order to maintain functional diversity.

Functional diversity has been pointed as a promising approach to developing ecological indicators, the fifth class of conservation strategies (see Figure 2A - Bello and Mudrak, 2013; Kachergis et al., 2013). Maintaining the quality of ecosystems functioning is one of the aims of biological conservation (Sodhi and Ehrlich, 2010; Trombulak et al., 2004). Given quality is a subjective concept, ecological indicators enable to turn it into objectives' parameters and connect it with conservation (Turnhout et al., 2007). Metrics of functional diversity of different organisms have been used as indicator of habitat quality and conservation values, and thus it bases recommendation of management and selection of priority areas to conservation (Leroy et al., 2014; Bishop and Myers, 2005; Maire et al., 2013). It can also be used to find 
biodiversity indicators in natural areas and agroecosystems (Kadoya et al., 2011; Trindade-Filho et al., 2012; Trivellone et al., 2014).

As plant ecology field started the first studies with functional diversity (Tilman et al., 1997; Grime, 1998; Díaz and Cabido, 1997, 2001), the high number of papers using plants is not surprising (see Figure 2B). Also, structure of vegetation is assumed to be associated with habitat diversity, which underscores its importance to conservation (Ricklefs, 2003). Indeed, functional groups of plants describe robust diversity of mammals, birds and termites (Gillison et al., 2013). On the other hand, it has also been found that successful restoration of plant diversity does not necessarily imply successful restoration of soil nematode functional diversity (Kardol et al., 2005). This contradiction raises the importance of studies that disentangle the relationships between functional diversity of different taxa. Fortunately, multitaxa and/or network is the class with the highest number of papers after plants (see Figure 2B).

Birds and Arthropoda are together in the third class of organisms studied (see Figure 2B). Since birds act as genetic linkers, carrying genetic information between habitats and most of Arthropoda are strongly associated with nutrient cycling (Lundberg and Moberg, 2003), functional diversity of these organisms has a great potential to be applied in conservation strategies. Basic knowledge of birds' functional diversity is fairly well explored (Petchey et al., 2007; Trindade-Filho et al., 2012). However, the inclusion of functional diversity of Arthropoda in conservation issues still needs more improvements such as defining appropriate functional diversity index for benthic macro invertebrate (Kadoya et al., 2011).

The number of papers published that have study sites located in Europe is more six times higher than the papers with study sites in Latin America, the second continent in the ranking (see Figure 2C). As most part of Europe lies in the northern temperate climate zone, current conclusions and recommendations regarding functional diversity and conservation tend to be less suitable to ecosystems from outside that climate. Because tropical species communities are prone to be more complex (Janzen, 1975; Vamosi et al., 2006), relationships between ecosystem functioning and functional diversity in the tropics may not be as straightforward, as is usually assumed (Freitas et al., 2012; Martins and Batalha, 2006). Testing hypothesis in tropical ecosystems would contribute to expanding the current understanding of functional diversity in conservation strategies' applicability.

In sum, our results show that the functional diversity approach entered the Biological Conservation field in the early 2000's and an extended peer community is expected to develop, apply and improve the knowledge. We found the inclusion of indices based on functional diversity on conservation strategies is broadly advised but the number of papers that operationalise such inclusion is still low. Functional diversity responds differently and eventually better than other measures to changes in land use and management suggesting that this approach can potentially better predict the impacts. More studies are needed to corroborate this hypothesis.

Our results highlighted lack of knowledge on identifying the responses of functional diversity to urban impacts and on the search for the level of management intensity of land needed to maintain functional diversity. We recommend use of the functional diversity approach to develop indicators of habitat quality, conservation value, and ecosystem services. Moreover, because the studies are strongly concentrated on plants and in European ecosystems, future studies should focus on other taxa apart from plants, and hypothesis tests in tropical ecosystems would also improve the applicability of functional diversity in conservation strategies.

\section{Acknowledgements}

We thank CAPES - Coordenação de Aperfeiçoamento de Pessoal de Nível Superior for the scholarship granted to JRF.

\section{References}

BALMFORD, A., GREEN, R. and PHALAN, B., 2012. What conservationists need to know about farming. Proceedings Biological Sciences The Royal Society, vol. 279, no. 1739, pp. 2714-2724. http://dx.doi.org/10.1098/rspb.2012.0515.

BELLO, F. and MUDRÁK, O., 2013. Plant traits as indicators: loss or gain of information? Applied Vegetation Science, vol. 16, no. 3, pp. 353-354. http://dx.doi.org/10.1111/avsc.12035.

BENNETT, J.R., ELLIOTT, G., MELLISH, B., JOSEPH, L.N., TULLOCH, A.I.T., PROBERT, W.J.M., DI FONZO, M.M.I., MONKS, J.M., POSSINGHAM, H.P. and MALONEY, R., 2014. Balancing phylogenetic diversity and species numbers in conservation prioritization, using a case study of threatened species in New Zealand. Biological Conservation, vol. 174, pp. 47-54. http://dx.doi.org/10.1016/j.biocon.2014.03.013.

BISHOP, J.A. and MYERS, W.L., 2005. Associations between avian functional guild response and regional landscape properties for conservation planning. Ecological Indicators, vol. 5, no. 1, pp. 33-48. http://dx.doi.org/10.1016/j.ecolind.2004.10.001.

BLÜTHGEN, N., 2011. Interações plantas-animais e a importância funcional da biodiversidade. In: K. DEL CLARO and H.M. TOREZAN-SILINGARDI, eds. Ecologia das interações plantasanimais: uma abordagem ecológico-evolutiva. Rio de Janeiro: Technical Books Editora, pp. 261-272.

CADOTTE, M.W., 2011. The new diversity : management gains through insights into the functional diversity of communities. Journal of Applied Ecology, vol. 48, no. 5, pp. 1067-1069. http:// dx.doi.org/10.1111/j.1365-2664.2011.02056.x.

CADOTTE, M.W., CARSCADDEN, K. and MIROTCHNICK, N., 2011. Beyond species: functional diversity and the maintenance of ecological processes and services. Journal of Applied Ecology, vol. 48, no. 5, pp. 1079-1087. http://dx.doi.org/10.1111/j.13652664.2011.02048.x.

CALLISTO, M., MORENO, P. and BARBOSA, F.A.R., 2001. Habitat diversity and benthic functional trophic groups at Serra do Cipó, Southeast Brazil. Brazilian Journal of Biology $=$ Revista Brasileira de Biologia, vol. 61, no. 2, pp. 259-266. http://dx.doi. org/10.1590/S0034-71082001000200008. 
CIANCIARUSO, M.V., SILVA, I.A. and BATALHA, M.A., 2009. Diversidades filogenética e funcional: novas abordagens para a Ecologia de comunidades. Biota Neotropica, vol. 9, no. 3, pp. 93-103. http://dx.doi.org/10.1590/S1676-06032009000300008.

CORNELISSEN, J.H.C., LAVOREL, S., GARNIER, E., DÍAZ, S., BUCHMANN, N., GURVICH, D.E., REICH, P.B., STEEGE, H., MORGAN, H.D., VAN DER HEIJDEN, M.G.A., PAUSAS, J.G. and POORTER, H., 2003. Handbook of protocols for standardised and easy measurement of plant functional traits worldwide. Australian Journal of Botany, vol. 51, no. 4, pp. 335-380. http:// dx.doi.org/10.1071/BT02124.

DENGLER, J., JANIŠOVÁ, M., TÖRÖK, P. and WELLSTEIN, C., 2014. Biodiversity of palaearctic grasslands: a synthesis. Agriculture, Ecosystems \& Environment, vol. 182, pp. 1-14. http://dx.doi.org/10.1016/j.agee.2013.12.015.

DÍAZ, S. and CABIDO, M., 1997. Plant functional types and ecosystem function in relation to global change. Journal of Vegetation Science, vol. 8, no. 4, pp. 463-474. http://dx.doi. org/10.2307/3237198.

DÍAZ, S. and CABIDO, M., 2001. Vive la différence: plant functional diversity matters to ecosystem processes. Trends in Ecology \& Evolution, vol. 16, no. 11, pp. 646-655. http://dx.doi. org/10.1016/S0169-5347(01)02283-2.

DÍAZ, S., LAVOREL, S., BELLO, F., QUÉTIER, F., GRIGULIS, K. and ROBSON, T.M., 2007. Incorporating plant functional diversity effects in ecosystem service assessments. Proceedings of the National Academy of Sciences of the United States of America, vol. 104, no. 52, pp. 20684-20689. PMid:18093933.

ELSEVIER, 2015 [viewed 12 February 2015]. Science Direct [online]. Available from: http://www.sciencedirect.com/

FILIPPI-CODACCIONI, O., CLOBERT, J. and JULLIARD, R., 2009. Urbanisation effects on the functional diversity of avian agricultural communities. Acta Oecologica, vol. 35, no. 5, pp. 705-710. http://dx.doi.org/10.1016/j.actao.2009.07.003.

FONTANA, V., RADTKE,A., WALDE, J., TASSER, E., WILHALM, T., ZERBE, S. and TAPPEINER, U., 2014. What plant traits tell us: consequences of land-use change of a traditional agroforest system on biodiversity and ecosystem service provision. Agriculture, Ecosystems \& Environment, vol. 186, pp. 44-53. http://dx.doi.org/10.1016/j.agee.2014.01.006.

FRANCIS, R.A. and GOODMAN, M.K., 2009. Post normal science and the art of nature conservation. London: Department of Geography, King's College London. 37 p. Environment, politics and development working paper series.

FRANCO, J.L.A., 2013. O conceito de biodiversidade e a história da biologia da conservação: da preservação da wilderness à conservação da biodiversidade. História, vol. 32, no. 2, pp. 21-48.

FREITAS, J.R., CIANCIARUSO, M.V. and BATALHA, M.A., 2012. Functional diversity, soil features and community functioning: a test in a cerrado site. Brazilian Journal of Biology $=$ Revista Brasileira de Biologia, vol. 72, no. 3, pp. 463-470.

FUNTOWICZ, S.O. and RAVETZ, J.R., 1993. Science for the post-normal age. Futures, vol. 25, no. 7, pp. 739-755. http:// dx.doi.org/10.1016/0016-3287(93)90022-L.

GASC, A., SUEUR, J., JIGUET, F., DEVICTOR, V., GRANDCOLAS, P., BURROW, C., DEPRAETERE, M. and PAVOINE, S., 2013. Assessing biodiversity with sound: do acoustic diversity indices reflect phylogenetic and functional diversities of bird communities? Ecological Indicators, vol. 25, pp. 279-287. http:// dx.doi.org/10.1016/j.ecolind.2012.10.009.

GILLISON, A.N., BIGNELL, D.E., BREWER, K.R.W., FERNANDES, E.C.M., JONES, D.T., SHEIL, D., MAY, P.H., WATT, A.D., CONSTANTINO, R., COUTO, E.G., HAIRIAH, K., JEPSON, P., KARTONO, A.P., MARYANTO, I., NETO, G.G., VAN NOORDWIJK, M., SILVEIRA, E.A., SUISILO, F.-X., VOSTI, S.A. and NUNES, P.C., 2013. Plant functional types and traits as biodiversity indicators for tropical forests : two biogeographically separated case studies including birds, mammals and termites. Biodiversity and Conservation, vol. 22, no. 9, pp. 1909-1930. http://dx.doi.org/10.1007/s10531-013-0517-1.

GITAY, H. and NOBLE, I.R., 1997. What are functional types and how should we seek them? In: T.M. SMITH, H.H. SHUGART and F. I. WOODWARD, eds. Plant functional types: their relvelance to ecosystem propoerties and global change. Cambridge: Cambridge University Press.

GRANGER, V., FROMENTIN, J.-M., BEZ, N., RELINI, G., MEYNARD, C., GAERTNER, J.-C., MAIORANO, P., RUIZ, C.G., FOLLESA, C., GRISTINA, M., PERISTERAKI, P., BRIND'AMOUR, A., CARBONARA, P., CHARILAOU, C., ESTEBAN, A., JADAUD, A., JOKSIMOVIC, A., KALLIANIOTIS, A., KOLITARI, J., MANFREDI, C., MASSUTI, E., MIFSUD, R., QUETGLAS, T., REFES, W., SBRANA, M., VRGOC, N., SPEDICATO, M.T. and MÉRIGOT, B., 2015. Large-scale spatio-temporal monitoring highlights hotspots of demersal fish diversity in the Mediterranean Sea. Progress in Oceanography, vol. 130, pp. 65-74. https://doi.org/10.1016/j.pocean.2014.10.002.

GRIME, J.P., 1998. Benefits of plant diversity to ecosystems: immediate, filter and founder effects. Journal of Ecology, vol. 86, no. 902-910, pp. 891-899.

HOOPER, D.U., CHAPIN, F.S. 3rd., EWEL, J.J., HECTOR, A., INCHAUSTI, P., LAVOREL, S., LAWTON, J.H., LODGE, D.M., LOREAU, M., NAEEM, S., SCHMID, B., SETALA, H., SYMSTAD, A.J., VANDERMEER, J. and WARDLE, D.A., 2005. Effects of biodiversity on ecosystem functioning: a consensus of current knowledge. Ecological Monographs, vol. 75, no. 1, pp. 3-35. http://dx.doi.org/10.1890/04-0922.

ISBELL, F., CALCAGNO, V., HECTOR, A., CONNOLLY, J., HARPOLE, W.S., REICH, P.B., SCHERER-LORENZEN, M., SCHMID, B., TILMAN, D., VAN RUIJVEN, J., WEIGELT, A., WILSEY, B.J., ZAVALETA, E.S. and LOREAU, M., 2011. High plant diversity is needed to maintein ecosystem services. Nature, vol. 477, no. 7363, pp. 199-202. PMid:21832994. http://dx.doi. org/10.1038/nature10282.

JANZEN, D.H., 1975. Ecology of plants in the tropics. London: Edward Arnold.

KACHERGIS, E., ROCCA, M.E. and FERNANDEZ-GIMENEZ, M.E., 2013. Comparison of species and trait-based approaches for describing segebrush steppe response to range management. Applied Vegetation Science 2, vol. 16, no. 3, 355-364.

KADOYA, T., AKASAKA, M., AOKI, T. and TAKAMURA, N., 2011. A proposal of framework to obtain an integrated biodiversity indicator for agricultural ponds incorporating the simultaneous effects of multiple pressures. Ecological Indicators, vol. 11, no. 5, pp. 1396-1402. http://dx.doi.org/10.1016/j.ecolind.2011.03.001.

KARDOL, P., BEZEMER, T.M., VAN DER WAL, A. and VAN DER PUTTEN, W.H., 2005. Sucessional trajectories of soil nematode and plant communities in a chronosequence of ex-arable 
lands. Biological Conservation, vol. 126, no. 3, pp. 317-327. http://dx.doi.org/10.1016/j.biocon.2005.06.005.

KATOVAI, E., BURLEY, A.L. and MAYFIELD, M.M., 2012. Understory plant species and functional diversity in the degraded wet tropical forests of Kolombangara Island, Solomon Islands. Biological Conservation, vol. 145, no. 1, pp. 214-224. http:// dx.doi.org/10.1016/j.biocon.2011.11.008.

KRAUSE, B. and CULMSEE, H., 2013. The significance of habitat continuity and current management on the compositional and functional diversity of grasslands in the uplands of Lower Saxony, Germany. Flora - Morphology, Distribution. Functional Ecology of Plants, vol. 208, no. 5-6, pp. 299-311. http://dx.doi. org/10.1016/j.flora.2013.04.003.

LAURETO, L.M.O., CIANCIARUSO, M.V. and SAMIA, D.S.M., 2015. Functional diversity: an overview of its history and applicability. Natureza \& Conservação, vol. 13, no. 2, pp. 112-116. http://dx.doi.org/10.1016/j.ncon.2015.11.001.

LEROY, B., LE VIOL, I. and PÉTILLON, J., 2014. Complementarity of rarity, specialisation and functional diversity metrics to assess community responses to environmental changes, using an example of spider communities in salt marshes. Ecological Indicators, vol. 46, pp. 351-357. http://dx.doi.org/10.1016/j.ecolind.2014.06.037.

LILLESKOV, E.A., HOBBIE, E.A. and HORTON, T.R., 2011. Conservation of ectomycorrhizal fungi: exploring the linkages between functional and taxonomic responses to anthropogenic $\mathrm{N}$ deposition. Fungal Ecology, vol. 4, no. 2, pp. 174-183. http:// dx.doi.org/10.1016/j.funeco.2010.09.008.

LUNDBERG, J. and MOBERG, F., 2003. Mobile link organisms and ecosystem functioning: Implications for ecosystem resilience and management. Ecosystems, vol. 6, no. 1, pp. 87-98. http:// dx.doi.org/10.1007/s10021-002-0150-4.

MACARTHUR, R.H., 1972. Geographical ecology. New York: Harper \& Row.

MAGURRAN, A.E., 2004. Measuring biological diversity. Oxford: Blackwell Publishing.

MAIRE, A., BUISSON, L., BIAU, S., CANAL, J. and LAFFAILLE, P., 2013. A multi-faceted framework of diversity for prioritizing the conservation of fish assemblages. Ecological Indicators, vol. 34, pp. 450-459. http://dx.doi.org/10.1016/j.ecolind.2013.06.009.

MARTINS, F.Q. and BATALHA, M.A., 2006. Pollination systems and floral traits in cerrado woody species of the Upper Taquari region (central Brazil). Brazilian Journal of Biology $=$ Revista Brasileira de Biologia, vol. 66, no. 2A, pp. 543-552.

MÉDAIL, F., ROCHE, P. and TATONI, T., 1998. Functional groups in phytoecology: an application to the study of isolated plant communities in Mediterranean France. Acta Oecologica, vol. 19, no. 3, pp. 263-274. http://dx.doi.org/10.1016/S1146609X(98)80030-1.

MEFFE, C.E. and CARROLL, C.R., 1963. Principles of conservation biology. Sunderland: Sinauer Associates.

MEINE, C., 2010. Conservation biology: past and present. In: N.S. SODHI and P.R. EHRLICH, eds. Conservation biology for all. Oxford: Oxford University Press, pp. 7-26.

MOUCHET, M.A., VILLÉGER, S., MASON, N.W.H. and MOUILLOT, D., 2010. Functional diversity measures: an overview of their redundancy and their ability to discriminate community assembly rules. Functional Ecology, vol. 24, no. 4, pp. 867-876. http://dx.doi.org/10.1111/j.1365-2435.2010.01695.x.
MOUILLOT, D., CULIOLI, J.M., PELLETIER, D. and TOMASINI, J.A., 2008. Do we protect biological originality in protected areas? A new index and an application to the Bonifacio Strait Natural Reserve. Biological Conservation, vol. 141, no. 6, pp. 1569-1580. http://dx.doi.org/10.1016/j.biocon.2008.04.002.

PELOSI, C., PEY, B., HEDDE, M., CARO, G., CAPOWIEZ, Y., GUERNION, M., PEIGNÉ, J., PIRON, D., BERTRAND, M. and CLUZEAU, D., 2014. Reducing tillage in cultivated fields increases earthworm functional diversity. Applied Soil Ecology, vol. 83, pp. 79-87. http://dx.doi.org/10.1016/j.apsoil.2013.10.005.

PÉREZ-HARGUINDEGUY, N., DÍAZ, S., GARNIER, E., LAVOREL, S., POORTER, H., JAUREGUIBERRY, P., BRETHARTE, M.S., CORNWELL, W.K., CRAINE, J.M., GURVICH, D.E., URCELAY, C., VENEKLAAS, E.J., REICH, P.B., POORTER, L., WRIGHT, I.J., RAY, P., ENRICO, L., PAUSAS, J.G., VOS, A.C., BUCHMANN, N., FUNES, G., QUÉTIER, F., HODGSON, J.G., THOMPSON, K., MORGAN, H.D., STEEGE, H., SACK, L., BLONDER, B., POSCHLOD, P., VAIERETTI, M.V., CONTI, G., STAVER, A.C., AQUINO, S. and CORNELISSEN, J.H.C., 2013. New handbook for standardised measurement of plant functional traits worldwide. Australian Journal of Botany, vol. 61, no. 3, pp. 167-234. http://dx.doi.org/10.1071/BT12225.

PERRY, N., 2010. The ecological importance of species and the Noah's Ark problem. Ecological Economics, vol. 69, no. 3, pp. 478-485. http://dx.doi.org/10.1016/j.ecolecon.2009.09.016.

PETCHEY, O.L. and GASTON, K.J., 2002. Functional diversity (FD), species richness and community composition. Ecology Letters, vol. 5, no. 3, pp. 402-411. http://dx.doi.org/10.1046/j.14610248.2002.00339.x.

PETCHEY, O.L. and GASTON, K.J., 2006. Functional diversity: back to basics and looking forward. Ecology Letters, vol. 9, no. 6, pp. 741-758. PMid:16706917. http://dx.doi.org/10.1111/j.14610248.2006.00924.x.

PETCHEY, O.L., EVANS, K.L., FISHBURN, I.S. and GASTON, K.J., 2007. Low functional diversity and no redundancy in British avian assemblages. Journal of Animal Ecology, vol. 76, no. 5, pp. 977-985. PMid:17714276. http://dx.doi.org/10.1111/j.13652656.2007.01271.x.

RICKLEFS, R.E., 2003. A economia da natureza. Rio de Janeiro: Guanabara Koogan.

ROBINSON, J.P.W., WHITE, E.R., WIWCHAR, L.D., CLAAR, D.C., SURACI, J.P. and BAUM, J.K., 2014. The limitations of diversity metrics in directing global marine conservation. Marine Policy, vol. 48, pp. 123-125. http://dx.doi.org/10.1016/j. marpol.2014.03.012.

SCHIRMEL, J., BLINDOW, I. and BUCHHOLZ, S., 2012. Lifehistory trait and functional diversity patterns of ground beetles and spiders along a coastal heathland successional gradient. Basic and Applied Ecology, vol. 13, no. 7, pp. 606-614. http://dx.doi. org/10.1016/j.baae.2012.08.015.

SCHULDT, A., ASSMANN, T. and SCHAEFER, M., 2013. Scale-dependent diversity patterns affect spider assemblages of two contrasting forest ecosystems. Acta Oecologica, vol. 49, pp. 17-22. http://dx.doi.org/10.1016/j.actao.2013.02.009.

SCHWARTZ, M.W., BRIGHAM, C.A., HOEKSEMA, J.D., LYONS, K.G., MILLS, M.H. and VAN MANTGEM, P.J., 2000. Linking biodiversity to ecosystem function: implications for conservation ecology. Oecologia, vol. 122, no. 3, pp. 297-305. PMid:28308280. http://dx.doi.org/10.1007/s004420050035. 
SODHI, N.S. and EHRLICH, P.R., 2010. Conservation biology for all. S.l.: s.n.

SRIVASTAVA, D.S., CARDINALE, B.J., DOWNING, A.L., DUFFY, J.E., JOUSEAU, C., SANKARAN, M. and WRIGHT, J.P., 2009. Diversity has stronger top-down than bottom-up effects on decomposition. Ecology, vol. 90, no. 4, pp. 1073-1083. PMid:19449701. http://dx.doi.org/10.1890/08-0439.1.

SWINTON, S.M., LUPI, F., ROBERTSON, G.P. and HAMILTON, S.K., 2007. Ecosystem services and agriculture: cultivating agricultural ecosystems for diverse benefits. Ecological Economics, vol. 64, no. 2, pp. 245-252. http://dx.doi.org/10.1016/j.ecolecon.2007.09.020.

TILMAN, D., KNOPS, J., WEDIN, D., REICH, P., RITCHIE, M. and SIEMANN, E., 1997. The influence of functional diversity and composition on ecosystem processes. Science, vol. 277, no. 5330, pp. 1300-1302. http://dx.doi.org/10.1126/science.277.5330.1300.

TRINDADE-FILHO, J. and LOYOLA, R.D., 2010. O uso de grupos indicadores como atalho para a conservação da biodiversidade. Revista de Biologia Neotropical, vol. 7, no. 2, pp. 27-38.

TRINDADE-FILHO, J. and LOYOLA, R.D., 2011. Performance and consistency of indicator groups in two biodiversity hotspots. PLoSOne, vol. 6, no. 5, pp. e19746. PMid:21637330. http://dx.doi. org/10.1371/journal.pone.0019746.

TRINDADE-FILHO, J., SOBRAL, F.L., CIANCIARUSO, M.V. and LOYOLA, R.D., 2012. Using indicator groups to represent bird phylogenetic and functional diversity. Biological Conservation, vol. 146, no. 1, pp. 155-162. http://dx.doi.org/10.1016/j. biocon.2011.12.004.

TRIVELLONE, V., SCHOENENBERGER, N., BELLOSI, B., JERMINI, M., BELLO, F., MITCHELL, E.A.D. and MORETTI, M., 2014. Indicators for taxonomic and functional aspects of biodiversity in the vineyard agroecosystem of Southern Switzerland.
Biological Conservation, vol. 170, pp. 103-109. http://dx.doi. org/10.1016/j.biocon.2013.12.008.

TROMBULAK, S.C., OMLAND, K.S., ROBINSON, J.A., LUSK, J.J., FLEISCHNER, T.L., BROWN, G. and DOMROESE., M., 2004. Princípios da biologia da conservação: diretrizes para o ensino da conservação recomendadas pelo comitê de educação da sociedade para a biologia da conservação. Conservation Biology, vol. 18 , no. 5 , pp. 1-11.

TURNHOUT, E., HISSCHEMÖLLER, M. and EIJSACKERS, H., 2007. Ecological indicators: between the two fires of science and policy. Ecological Indicators, vol. 7, no. 2, pp. 215-228. http://dx.doi.org/10.1016/j.ecolind.2005.12.003.

VAMOSI, J.C., KNIGHT, T.M., STEETS, J.A., MAZER, S.J., BURD, M. and ASHMAN, T.-L., 2006. Pollination decays in biodiversity hotspots. Proceedings of the National Academy of Sciences of the United States of America, vol. 103, no. 4, pp. 956961. PMid:16418284. http://dx.doi.org/10.1073/pnas.0507165103.

VAN CAPELLE, C., SCHRADER, S. and BRUNOTTE, J., 2012. Tillage-induced changes in the functional diversity of soil biota - A review with a focus on German data. European Journal of Soil Biology, vol. 50, pp. 165-181. http://dx.doi.org/10.1016/j. ejsobi.2012.02.005.

VILLÉGER, S., MASON, N.W.H. and MOUILLOT, D., 2008. New multidimensional functional diversity indices for a multifaceted framework in functional ecology. Ecology, vol. 89, no. 8, pp. 2290-2301. PMid:18724739. http://dx.doi.org/10.1890/07-1206.1.

WINTER, M., DEVICTOR, V. and SCHWEIGER, O., 2013. Phylogenetic diversity and nature conservation: where are we? Trends in Ecology \& Evolution, vol. 28, no. 4, pp. 199-204. PMid:23218499. http://dx.doi.org/10.1016/j.tree.2012.10.015. 